\title{
ON TESNIÈRE ON THE DUAL
}

Duals come and go almost everywhere, or have done so some time or other, but it is rare for such events to be chronicled so circumstantially as Lucien Tesnière did for Slovenian in his well-known chef-d'oeuvre of 1925. Tesnière's chief interest was to collect enough information to be able to chart comprehensively the dual's demise and partial renaissance in the varieties of Slovenian, dialectal as well as literary, and to identify the changes concerned as phonological, morphological (in particular analogical), or syntactic. Although he would sometimes compare Slovenian patterns and developments to others, especially Slavonic and Indo-European ones, he was reluctant to draw general conclusions from the particulars so amply at his disposal other than implicitly, occasionally hinting at "tendences" or "causes profondes" supposedly giving direction to the vagaries of phonetics and morphology.

Nonetheless, on account of their very detail, it is instructive to see how Tesnière's Slovenian findings bear on generalisations about the dual. Particular attention will be paid (a) to the actual mechanisms responsible for the reduction and loss or the innovation, renovation, or reactivation of duals, and (b) to patterns of dual extensions, with dualworthiness defined in terms of hierarchical rankings of wordclasses and inflectional categories, such as Personal Pronoun Numeral/ Quantifier 2/both Noun Demonstrative Adjective, Nominative-Accusative Instrumental Dative Genitive Locative, Masculine Neuter Feminine, 1st/2nd 3rd Person, as suggested by Tesnière for Slovenian but not necessarily as universal, with duals supposedly disappearing from right to left and to be innovated or renovated from left to right on such scales.

Povzetek

TESNIERJEV POGLED NA DVOJINO

\footnotetext{
Dvojine se pojavljajo in izginjajo, vendar pa so ti dogodki redko kdaj zabeleženi s tako natančnostjo, kot je to za slovenščino storil Lucien Tesnière v svojem znamenitem delu iz 1. 1925. Tesnièrjev glavni namen je bil zbrati dovolj podatkov, s katerimi bi na razumljiv način pojasnil ostanke in delno renesanso dvojine v knjižni in narečni slovenščini, ter ugotoviti fonološke, oblikoslovne (zlasti analogne) in skladenjske spremembe. Čeprav je slovenske vzorce in razvojne oblike včasih primerjal $z$ ostalimi, zlasti slovanskimi in indoevropskimi, je iz posamičnih primerov, le-teh je imel na razpolago obilo, nerad izpeljeval splošne zaključke; le občasno in implicitno je namignil na kake "tendence" ali "globoke vzroke", ki naj bi pripeljali do določenih fonetičnih in oblikoslovnih muhavosti.
} 
Poučno pa je, kako se Tesnièrjeva odkritja glede slovenščine nanašajo tudi na splošne ugotovitve o dvojïni. Posebna pozornost bo namenjena (a) sedanjim mehanizmom, zaradi katerih prihaja do zmanjšanja in izgube ali pa do nastanka, obnove oz. ponovne uporabe dvojine in (b) vzorcem širjenja dvojine ter njeni vrednosti, opredeljeni glede na hierarhično razporeditev besednih vrst in pregibnih oblik, kot so osebni zaimek, števnik 'dva/oba', samostalnik, kazalni zaimek, pridevnik; imenovalnik-tožilnik, orodnik, dajalnik, rodilnik, mestnik; moški, srednji, ženski spol; 1./2., 3. oseba. Tesnière predpostavlja, da dvojina v slovenščini, ne pa tudi na splošno, izginja $z$ desne proti levi ter se obnavlja oz. prenavlja $z$ leve proti desni strani navedenih lestvic. 